\title{
Protection of Indonesian Migrant Workers through One-Stop Service for Placement and Protection of Indonesian Migrant Workers
}

\author{
Dian Cahyaningrum ${ }^{1}$, Luthvi Febryka Nola ${ }^{2}$ \\ \{cahyaningrum@yahoo.com ${ }^{1}$, febi_80@yahoo.com ${ }^{2}$ \} \\ Center for Research of the Indonesian House of Representatives, Indonesia ${ }^{1,2}$
}

\begin{abstract}
The number of illegal Indonesian Migrant Workers (IPMI) continues to increase. To that end, the Law Number 18 of 2017 on Protection of Indonesian Migrant Workers has stipulated the establishment of a program known as One-Stop Service for Placement and Protection of PMI (LTSA). This program is expected to prevent and reduce the number of illegal PMIs. However, not all regions have created such program. For this reason, this study aims at raising the issue on how to regulate the program, how to identify the difficulties in implementing it, and how to find the solutions. With normative legal research method and secondary data, the study shows that LTSA has been regulated under the Law Number 18 of 2017 and the Government Regulation Number 59 of 2021. The program offers placement and protection services for PMIs in an integrated and coordinated manner. However, it has faced several difficulties in its implementation including: the establishment of the program is merely a recommendation; the program is not clearly regulated; the implementing regulations are not immediately formed; lack of coordination; and the human resources, budget and infrastructure are limited. In addition, the public opinion on the difficulty in arranging formal departure also affects the PMI interest in LTSA. In some regions, illegal departure through a third party has also become a culture. These difficulties have resulted in the placement and protection of PMI through the program to not work optimally. Therefore, to overcome such difficulties, the Law Number 18 of 2017 must be revised immediately.
\end{abstract}

Keywords: LTSA, PMI, Illegal PMI, Placement, Protection Services

\section{Introduction}

The number of illegal Indonesian Migrant Workers (Pekerja Migran Indonesia/PMI) overseas is quite alarming. As stated by the Head of the Indonesian Migrant Worker Protection Agency (Badan Pelindungan Pekerja Migran Indonesia/BP2MI), Benny Rhamdani, the number of PMI officially and legally registered at BP2MI is about 3.7 million and spread over 150 countries. However, based on data from the World Bank says on the contrary, the number of PMI overseas reaches 9 million people. A significant difference around 5.3 million PMI that are not recorded at BP2MI. Approximately 80 percent of the people in the figure have allegedly taken illegal procedures to arrive in the country of placement [1]. In addition, within a year serving as Head of BP2MI, Benny Rhamdani has thwarted 610 people who went overseas to work illegally. The illegal PMI were sent by mafia who are backed up by people with attributes 
of power, including police, TNI, Immigration, Embassy, Ministry of Manpower, and BP2MI itself [2].

Ironically, the number of illegal PMI is predicted to increase during the Corona Virus Disease 2019 (Covid-19) pandemic, which has hit the world since March 2020 and has not shown any signs to stop spreading. Executive Director of Migrant Care, Anis Hidayah predict that the number of illegal PMI, those without official documents, will rise up by $30-40 \%$ compared to the last year's number. The number of illegal PMI in the last year period estimated based on the number of placements reaches 21,000 people [3].

The increase in the number is, on the one hand, mainly affected by the fact that the job market in the country has not recovered due to the pandemic. On the other hand, Indonesia is still considered to having difficulty finding countries of placement as the end of the pandemic is unclear [3]. Further, the Covid-19 pandemic has also caused the number of unemployed to increase for many affected companies have laid off their employees. The unemployment rate in Indonesia has increased from $4.9 \%$ to $7 \%$ (9,7 million people) during the pandemic [4]. This unemployment also consequently drives the PMI to work overseas illegally due to the pressure to make ends meet.

The increasing number of illegal PMI needs serious attention as they are prone to problems and human rights violations. Some of the problems include unpaid salary, physical abuse, sexual harassment, human trafficking, and even death. These problems can happen due to the fact that they are not recorded, which consequently leads to limited protection, on the one hand. On the other hand, they are unable and afraid to report what has happened to them because they must deal with the local law enforcement officials. They can be threatened with being deported or repatriated by the government in the country of placement as they do not have official documents. The number of repatriated PMI is quite large. As stated by Rhamdani, 169,000 PMI were repatriated, excluding 760 bodies and 640 ill PMI from January 2020 to mid-March 2021 [2].

In view of these cases, the PMI must work overseas legally, in accordance with the provisions of the applicable laws and regulations, in order to have full protection. To protect them, Indonesia has established Law Number 18 of 2017 on Protection of Indonesian Migrant Workers (Undang-Undang Nomor 18 Tahun 2017 tentang Pelindungan Pekerja Migran Indonesia) which has come into force since November 22, 2017. Law Number 18 of 2017 replace Law Number 39 of 2004 on Placement and Protection of Indonesian Workers Abroad (Undang-Undang Nomor 39 Tahun 2004 tentang Penempatan dan Pelindungan Tenaga Kerja Indonesia), which is no longer in line with the development of PMI protection needs. One of the sub-substances regulated in Law Number 18 of 2017, which is not regulated under the Law Number 39 of 2004 is one-stop service for placement and protection of Indonesian Migrant Workers (Layanan Terpadu Satu Atap/LTSA).

The LTSA is one of the programs intended to improve the PMI placement and protection management and to serve the community. It offers legal certainty and convenience in the PMI placement services in order to reduce, prevent, and even eliminate any illegal PMI. In addition, this program will record and protect them before, during, and after working overseas. Given its significance, the Ministry of Manpower has continued to encourage the role of local governments to establish and reinforce its establishment to improve its governance, services, and protection. The LTSA has only been established in 45 locations throughout Indonesia so far [5].

For those reasons, this study aims to examine the LTSA in relation to PMI protection. The issues proposed here are as follow: 1) how the LTSA is regulated; 2) How the LTSA services 
are implemented and what the barriers to the implementation are; and 3) What the possible solutions to overcome the barriers in the implementation are.

Studies about the LTSA in relation to PMI protection have been conducted by some researchers, including Afdal and Felicia who specifically wrote the effectiveness of the LTSA in Batam in reducing the number of illegal PMI overseas [6]. This writing is a sociological legal research which examines the effectiveness of the LTSA in Batam and the efforts to take to increase it. In another study, Nuraeni and Yuliastuti [7] analyzed the effectiveness of LTSA to protect PMI. The writing analyzes the effectiveness of LTSA in Cirebon and Kupang. The two studies were written before the establishment of the Government Regulation Number 59 of 2021 as the implementing regulations of the Law Number 18 of 2017 which regulates the LTSA. Therefore, in contrast to several previous studies, this study comprehensively examines the regulation of LTSA after the establishment of the Government Regulation Number 59 of 2021 , the implementation of the LTSA along with its barriers, and the solutions to overcome the barriers.

\section{Research Method}

This study is a normative legal research, which is conducted based on library research by analyzing secondary data [8]. It uses two types of secondary data; primary legal materials (legislation) and secondary legal materials (explain primary legal materials) [8]. The primary legal materials referred to related laws such as Law Number 18 of 2017, Government Regulation Number 59 of 2021 concerning the Protection of Indonesian Migrant Workers, etc. In the meantime, the secondary legal materials include books and journals. The data, in turn, are analyzed using descriptive qualitative method by accurately describing a particular situation or phenomenon [9] and understanding it in depth [10].

\section{Result and Discussion}

\subsection{The One-Stop Service for Placement and Protection of Indonesian Migrant Workers Regulation}

In the Law Number 18 of 2017, PMI is every Indonesian worker who meets the requirements as job seekers who are willing to work overseas and registered in the local government agencies responsible for the manpower affairs. In the meantime, PMI is every Indonesian citizen who will work, is currently working, or has worked to earn wages outside the Republic of Indonesia territory. Referring to this definition, PMI includes: 1) those who work for an employer with a legal entity; 2) those who work for individual or household employers; and 3) seafarers and fishers.

The PMI placement is undertaken according to the provisions of the applicable laws and regulations; the Law Number 18 of 2017 and the Government Regulation Number 59 of 2021 as its implementing regulations. Any placement which does not follow the legal procedures will lead the PMI to be illegal. Here, illegal procedures include documents and personal data falsification and manipulation; incomplete documents; ignorance to the placement procedures and mechanisms that have been set under the laws and regulations; and absence of work visa 
[11]. Several factors driving illegal PMI are low education, limited employment opportunities, and poverty. These factors have resulted in an increase in the number of illegal PMI during the Covid-19 pandemic. Other factors include limited access to information and lack of public knowledge on the procedures of PMI placement and protection. In addition, persuasion, enticement, and temptation to get high salary in a simple process from irresponsible individuals (brokers in this case) are also the factor causing illegal PMI [11].

Therefore, to prevent illegal PMI and increase PMI protection and their families, the Law Number 18 of 2017 which is better than the Law Number 39 of 2004 regulates placement and protection services. Based on Article 38 paragraph (1) of the Law Number 18 of 2017, the placement and protection services are undergone by the central and local governments in a coordinated and integrated manner. In providing such services, they can both establish an LTSA. The Law Number 18 of 2017 mandates to further regulate the LTSA under the government regulations. As the implementation of this mandate, the Government Regulation Number 59 of 2021 is applied and has come into force since April 7, 2021.

The Government Regulation Number 59 of 2021 mentions that the LTSA is a service system which provides information, fulfills requirements, and handles PMI problems. The system is integrated in an inexpensive, easy, and efficient public service without discrimination (Article 1 Number 19). Basically, the establishment of LTSA is taken to create and improve effective, efficient, transparent, fast, and high-quality services without discrimination and in a coordinated and integrated manner. For this reason, the establishment is considered essential, especially to areas where the PMI come from (areas of origin), crossing areas, and other areas with certain criteria set by the Minister.

With the establishment of LTSA, PMI placement and protection services can be completed effectively, efficiently, inexpensively, and quickly as the LTSA coordinates and integrates eight agencies or institutional services in term of desks. The eight desks include manpower; complaints and information; citizenship and civil registration; health; immigration; police; complaints and information; Citizenship and Civil Registration; health; immigration; police; banking; and social security. These 8 desks are intended to bring the placement and protection services closer to PMI in terms of : a) job market information; b) procedures for the placement and protection of PMI; c) counseling and job guidance; d) information for obtaining education and job training; e) information on the implementation of the PMI placement; $f$ ) job seeker registration services; g) verification of placement agreements, work agreement and work visa documents; $h$ ) verification of population data; i) information and access to health examination facilities; $j$ ) issuance of passports; $k$ ) issuance of police record certificate; l) banking information and services; and $\mathrm{m}$ ) information on social security membership services.

The LTSA also works as an organizer for pre-departure orientation, an activity to provide briefing and information for PMI who will go and work overseas, so they can have mental readiness and knowledge to work overseas, understand their rights and obligations and are able to overcome any problems they will face (Article 1 number 11 of the Government Regulation Number 59/2021). In addition, the LTSA also runs as a place for consultation, mediation, advocacy, and legal assistance for CPMI, PMI, and/or their families.

The PMI placement and protection service is carried out in coordination with the relevant agencies at the center and the region levels and according to the provisions of the legislation. Due to the information technology advances, the implementation of LTSA is available on an integrated online system between the central and local governments for effectiveness and efficiency.

In view of the fact that the LTSA is formed by the governor and/or the regent or mayor, the responsibility for the formation also rests with them. Their duties and responsibilities in 
implementing the LTSA are: 1) providing facilities for information technology-based PMI placement and protection service system; 2) allocating budget for the LTSA operations in accordance with their authority; 3 ) ensuring the implementation of services for PMI by assigning relevant apparatus personnel in the related local government; and 4) controlling the implementation of LTSA.

Further, the Government Regulation Number 59/2021 stipulates that the head of provincial government and/or the head of district or city government, ex officio, act as the persons in charge of the LTSA. As the persons in charge, their duties include the followings: 1) coordinating and controlling the implementation of LTSA; 2) determining the technical implementer for the implementation of LTSA proposed by the agencies that run it; 3) guaranteeing the quality of PMI placement and protection services according to the provisions of the legislation; 4) reporting the implementation of LTSA to the Minister who runs the manpower affairs through the governor at the provincial LTSA or the regent or mayor at the district or city LTSA. In carrying out their duties, the persons in charge are responsible to the governor or the regent or mayor. In connection with the 8 desks at the LTSA, the LTSA membership also consists of elements that run in the fields of manpower, population administration, health, immigration, police, psychology, banking, and social security.

\subsection{Barriers in the Implementation of LTSA Services and Protection}

The Law Number 18 of 2017 has regulated the existence of LTSA which is designed as a service system for PMI. After being enacted for almost four years, the Law has led to the establishment of a number of LTSAs organizing PMI departures in several provinces and/or districts or cities. The law enforcement theory offered by Soerjono Soekanto is used to find out the barriers faced by the local governments in establishing the LTSA. According to him, five factors affect the enactment of a law or regulation. The factors include 1) the law itself; 2) the law enforcement; 3) facilities and infrastructure; 4) culture; and 5) community [12].

Legally, the barrier results from the Law Number 18 of 2017 itself which does not require the local governments to establish an LTSA, but only recommends that they do so. Such recommendation is literally seen from the word "can" in Article 40 letter i and Article 41 letter k. In addition, Article 30 paragraph (4) of the Government Regulation Number 59/2021 also mentions that the recommendation for establishing an LTSA focuses on the PMI's areas of origin, their crossing areas, and areas with certain criteria. Consequently, not all provinces and/or districts or cities have established one. Another barrier to happen is due to the fact that both the Law Number 18 of 2017 and the Government Regulation Number 59/2021 do not specifically and clearly mention the LTSA design. Such barrier has resulted in the provincial and/or district or city governments having different attitudes towards the establishment of LTSA. Some are waiting for the formation of laws and regulations that specifically regulate it including North Sumatra, and some have established it such as Cirebon, Indramayu and Subang. Some others have designed it by integrating it with public service centers. This includes Banyumas, Banyuwangi, Kebumen, Batang, and Pamekasan [13].

Like the Government Regulation Number 59 of 2021, the Law Number 18 of 2017 only regulates the LTSA in general. Only one article, Article 38 in this case, specifically regulates it. The three remaining articles include Article 8 paragraph (3) which is related to the technical protection for PMI before working, Article 40 mentioning the duties and responsibilities of the provincial government, and Article 41 associated with the duties and responsibilities of district or city governments. The Law further mandates to regulate the LTSA under the Government Regulation. The general regulations in a law have a positive side. They can last longer and are 
more flexible. However, they do not apply legal certainty. The Government Regulation which specifies the existence of LTSA does not come at the right time. Article 90, for example, has actually stated the time limit for the Government Regulation, which is 2 years after the Law is enacted. However, the government has violated the time limit and the regulation on LTSA has only been made available since in April 2021. Even more sadly, this Government Regulation is incorporated with the Government Regulation Number 59 of 2021 on the Implementation of PMI Protection, not the Government Regulation which specifically deals with the LTSA.

Further, there seems to be an inconsistency between Article 8 paragraph (3) of the Law Number 18 of 2017 and the general provisions. The Law, for instance, mentions that the LTSA is a form of technical protection for PMI before working, while the general provisions mentions it as an administration or document service. Such inconsistency can certainly confuse the law enforcers. The technical protection and administrative protection have different meanings. The technical protection means protection in terms of work security and safety [14], whereas the administration suggests completing documents and determining work terms and conditions [15]. Consequently, the protection services provided by the LTSA commonly vary. Some merely serve administration process, and others attempt to protect and help solve the problems faced by CPMI or PMI.

In term of the law enforcers or implementers, the LTSA has experienced lack of coordination among the related agencies. The eight desks or agencies/institutions which organize the PMI placement and protection services include the Ministry of Manpower with job vacancies, the Ministry of Law and Human Rights with travel documents (passports), the Ministry of Health with medical examination facilities, the Police with police records, the Ministry of Home Affairs with the integrated service system and population information; and BPJS (Badan Penyelenggara Jaminan Sosial/Social Security Administrator) with PMI social security. Basically, such coordination plays an important role in an integrated service. However, in practice, each agency encounters sectoral ego in view of budgets and data confidentiality. This has led a number of important agencies running PMI services are reluctant to join the LTSA, including the immigration service to process passport for data security.

In regard to facilities and infrastructure, the LTSA requires similar places where services are carried out in an integrated manner. Unfortunately, not all regions have the budget to provide them. Service facilities including computers are also limited. In addition, the poor internet network in some areas has also become an obstacle in providing online placement and protection services for PMI. Further, the quality and number of human resources required by the LTSA is very limited in the regions, whereas an integrated PMI data collection system is very much needed. Such data collection system certainly requires significant funding and resources. There has not been a single integrated PMI data collection system to date. The BP2MI has its own PMI data on its Sistem Komputerisasi Tenaga Kerja Asing/SISKOTKLN (Computerized System for Foreign Workers). Similarly, the Ministry of Manpower has its own system. Regarding the number of PMI, the data at the district/city level varies. Here, the data on the repatriation of PMI is not even available. In practice, the LTSA does not serve the PMI until they return to their areas of origin. During the Covid-19 pandemic, in particular, this data plays a significant role in supporting their administration. With accurate data, the PMI protection is expected to carry out properly.

According to the cultural perspective, being an illegal PMI has become a culture. The PMI are also accustomed to using the third party or broker services to arrange their departure due to practicality and simplicity, their ignorance of PMI placement procedures, and so on. Using the third party of broker services undeniably provoke problems, including the amount of levies and document manipulation which leads to illegal PMIs. In view of the community perspective, the 
PMI's home of origins are generally conservative and are not familiar with an integrated service system. The only thing they know is that they have to follow procedures and provide documents from different agencies to be able to work overseas, in which the process is money and time consuming.

\subsection{Solution}

Referring to the barriers in implementing the LTSA regulations, the establishment and implementation of LTSA for PMI is not as simple as it seems considering many factors, including coordination among agencies, funding and human resources, are involved. The general LTSA regulations mentioned in the Law Number 18 of 2017 and the absence of obligation to establish an LTSA according to the Government Regulation Number 59 of 2021 causes the barriers to be unaddressed. In the meantime, the LTSA plays very important part especially in preventing illegal PMI. To this end, the obligation on its establishment needs to be clearly mentioned in the Law. In addition, types of services are also stated and properly provided as they involve many factors, not merely technical factors. Here, the types of service will affect each and every agency involved. If, they are clearly stated, the relevant agency will take full responsibility. The scope of service also needs to be addressed to identify departure or repatriation preparation. Most of the existing LTSA only provide departure preparation service. In view of the general explanation mentioned in the Law Number 18 of 2017, repatriation is part of the LTSA service.

Basically, the LTSA is required to provide repatriation service for PMI as the stakeholders in the LTSA organize the same service. Here, an integrated repatriation service needs to be implemented as it does not ideally stop when the PMI return to their home of origins, but also reintegrates the process both socially and economically. In Sri Lanka, for example, repatriation service is designed and organized in an integrated manner by a special agency, the Sri Lanka Bureau of Foreign Employment/SLBFE (Sri Lanka) [16]. However, as Indonesia does not own a special agency that organizes such service, and many stakeholders are involved it, this leads to the LTSA as a one stop service for repatriation to play an important role.

Due to the large number of stakeholders and systems taking part in PMI data collection, the Law needs to points out that the LTSA needs to be supported by an integrated data collection system, which can accordingly make the study of PMI policies to be more effective. In addition, such system can also offer online service, which is likely to do by the LTSA, to accommodate and manage administration such as the Philippines having currently designed One-Stop Service Center for Overseas Filipino Workers (OSSCO) [17]. Nevertheless, the PMI data security system must be taken into account.

To increasingly gain public trust in the LTSA performance, the Law needs to set time limit for the provided services and impose strict sanctions if the time limit is ignored. A clear formulation in the law will certainly be followed by implementing regulations. Additionally, human resources, budgets and internet networks also require attention and improvement, especially from the local governments. Here, they also need to socialize the importance of becoming legal PMI. 


\section{Conclusion}

The LTSA is regulated under the Law Number 18 of 2017 along with its implementing regulations, the Government Regulation Number 59 of 2021. It plays an important role in providing placement and protection services for CPMI, PMI, and/or their families. With its existence, the placement and protection services can be undertaken in an integrated and coordinated manner among the relevant agencies at the center and in the regions and in line with the provisions of the legislation. Such integration and coordination enables the placement and protection services to carry out effectively, efficiently, quickly, easily, and inexpensively. In addition, it is expected to prevent, reduce, and even eliminate any illegal PMI.

In the implementation process, the PMI services and protection through the LTSA have faced a number of barriers ranging from ambiguity, inconsistency to delays in the formulation of implementing regulations that lead to legal uncertainty. This is seen from the fact that not all regions have established an LTSA. Limited facilities and infrastructure including funding, internet network, and human resources also hinder the establishment. At least, conservative community and cultural factors greatly influence the PMI to take the illegal procedures.

Therefore, the LTSA regulations mentioned in the Law Number 18 of 2017 require reinforcement and details. Here, the Law is expected to be able to regulate the LTSA in more details by including the definition of the LTSA (in term of articles, not explanations), institution, scope of service, its specificities compared to other integrated service institutions, support for an integrated PMI data collection system, funding, time limit for the services and LTSA socialization to the community.

\section{References}

[1] A. Warsudi, "Jutaan TKI Illegal di Luar Negeri, Ratusan Pulang Dalam Peti Mati,” iNews, 2021. [Online]. Available: https://jabar.inews.id/berita/jutaan-tki-ilegal-di-luar-negeri-ratusan-pulangdalam-peti-mati.

[2] A. A. Purbaya, "5,3 Juta Pekerja Migran RI Diperkirakan ke Luar Negeri Illegal," Detik Finance, 2021. .

[3] R. Fauzan, “Jumlah PMI Illegal Diprediksi Meningkat Tahun Ini,” Bisnis.com, 2021.

[4] Kompas, "Pandemi Covid-19, Jumlah Pengangguran di Indonesia Naik 9,7 Juta Orang," Kompas, 2021. [Online]. Available: https://regional.kompas.com/read/2021/03/10/160618878/pandemicovid-19-jumlah-pengangguran-di-indonesia-naik-97-juta-orang.

[5] A. Ahmad, "Kemnaker Dorong Pelindungan PMI Melalui Pembentukan LTSA di Daerah," Berita Satu, 2021. .

[6] F. Felicia, "Efektivitas Layanan Terpadu Satu Atap (ltsa) Kota Batam dalam Menekan Jumlah Pekerja Migran Indonesia yang Illegal di Luar Negeri.” Universitas Internasional Batam, 2020

[7] Y. Nuraeni and A. Yuliastuti, "Analisis Efektifitas Layanan Terpadu Satu Atap Dalam Rangka Melindungi Pekerja Migran Indonesia," SEMINASTIKA, vol. 2, no. 1, pp. 24-34, 2019.

[8] S. Soekanto and S. Mamudji, "Penelitian hukum normatif: Suatu tinjauan singkat," 2001.

[9] S. Mamudji and H. Rahardjo, "Metode Penelitian dan Penulisan Hukum," Jakarta Badan Penerbit Fak. Huk. Univ. Indones., 2005.

[10] T. Erwinsyahbana and R. Ramlan, "Penelitian Kualitatif Bidang Ilmu Hukum dalam Prespektif Filsafat Konstruktivis," Borneo Law Rev. J., vol. 1, no. 1, pp. 1-19, 2017.

[11] Deputi Bidang Perlindungan BNP2TKI, "Pencegahan Pekerja Migran Indonesia (PMI) Non Prosedural," BNP2TKI. .

[12] S. Soekanto, "Faktor-faktor yang mempengaruhi penegakan hukum," 2007.

[13] F. Febrinastri, "Layanan Terpadu Satu Atap Bisa Kurangi Jumlah Pekerja Migran Non 
Prosedura," Suara.com, 2020.

[14] A. Khakim, Pengantar hukum ketenagakerjaan Indonesia: berdasarkan Undang-Undang nomor 13 tahun 2003. Citra Aditya Bakti, 2003.

[15] Pemerintah Republik Indonesia, Pasal 8 ayat (2) Undang-Undang Nomor 18 Tahun 2017 tentang Perlindungan Tenaga Kerja Indonesia. 2017.

[16] Ministry of Foreign Employment Sri Langka, "Sub policy and National Action Plan on Return and Reintegration of Migrant Workers Sri Lanka," ILO, 2015.

[17] Philippine Overseas Employment Administration, "Online Services - One-Stop Service Center for Overseas Philippine Workers," Philippine Overseas Employment Administration. . 